PENGARUH PERSEPSI TAX AMNESTY DAN

\title{
PENGETAHUAN WAJIB PAJAK BADAN TERKAIT UU NO 11 TAHUN 2016 TERHADAP KEPATUHAN WAJIB PAJAK BADAN
}

\author{
Ely Kartikaningdyah, Fanny Oktaveny \\ * Politeknik Negeri Batam \\ Program Studi Akuntansi Manajerial, \\ Jl. Ahmad Yani, Batam Centre, Batam 29461, Indonesia \\ ely@polibatam.ac.id, fanny.poltek@gmail.com
}

\begin{abstract}
Abstrak
Penelitian ini bertujuan untuk mengetahui pengaruh Persepsi Tax Amnesty dan Pemahaman Undang-Undang No.11 Tahun 2016 terhadap Kepatuhan Wajib Pajak Badan di Kota Batam. Teknik penentuan sampel menggunakan non probability sampling (Non Acak) berupa purposive sampling dengan jumlah sampel sebanyak 140 wajib pajak badan. Jenis data yang digunakan adalah data primer. Metode pengumpulan data dilakukan dengan kuesioner. Analisis data menggunakan analisis regresi berganda dengan menggunakan SPSS 22.0. Hasil penelitian menunjukkan bahwa Persepsi Tax Amnesty berpengaruh terhadap Kepatuhan Wajib Pajak Badan, dan Pemahaman Undang-Undang No.11 Tahun 2016 berpengaruh terhadap Kepatuhan Wajib Pajak Badan. Persepsi Tax Amnesty dan Pemahaman Undang-Undang No.11 Tahun 2016 secara bersama-sama atau simultan berpengaruh terhadap kepatuhan wajib pajak badan. Keterbatasan pada penelitian ini adalah penelitian hanya berdasarkan hal-hal yang terkait tax amnesty dan konsentrasi responden yang tidak maksimal. Pada penelitian ini disarankan untuk menambah sampel penelitian dan memperhatikan koresponden saat akan diajukan pertanyaan agar mendapatkan hasil yang lebih akurat. Penelitian dapat berguna bagi pihak KPP Madya Kota Batam sebagai referensi dalam mengevaluasi program-program pajak yang dijalankan dan ketetapan peraturan yang akan dijalankan dikemudian hari.
\end{abstract}

Kata kunci: Tax Amnesty, Undang-Undang No.11 Tahun 2016, Kepatuhan Wajib Pajak Badan.

\begin{abstract}
This study aims to determine the effect of Tax Amnesty Perception and Understanding Act No.11 of 2016 against Taxpayer Compliance Agency in Batam City. The technique of determining the sample using non probability sampling (non random) in the form of purposive sampling with the number of samples as many as 140 corporate taxpayers. The type of data used is the primary data. Methods of data collection were conducted by questionnaire. Data analysis using multiple regression analysis using SPSS 22.0. The results of the research indicate that Perceptions of Tax Amnesty affect the Taxpayer Compliance Agency, and Understanding Act No.11 of 2016 affect the Taxpayer Compliance Agency. Perceptions of Tax Amnesty and Understanding of Law No.11 of 2016 together or simultaneously affect the compliance of corporate taxpayers. Limitations in this study is the study only based on things related to tax amnesty and concentration of respondents who are not maximal. In this study it is suggested to add sample research and pay attention to the correspondent when will be asked questions in order to
\end{abstract}


get more accurate results. Research can be useful for the KPP Madya Kota Batam as a reference in evaluating the tax programs that run and the provisions of the rules that will be implemented in the future

Keywords: Tax Amnesty, Law No.11 of 2016, Corporate Taxpayer Compliance.

\section{Pendahuluan}

Pajak mempunyai peranan yang sangat penting dalam kehidupan bernegara, khususnya untuk pelaksanaan pembangunan. Dalam perekonomian negara, pajak merupakan sumber pendapatan negara yang digunakan untuk membiayai pengeluaran-pengeluaran negara, baik yang bersifat rutin maupun non rutin. Pajak juga merupakan salah satu tolak ukur dari keberhasilan perekonomian suatu negara. Pajak merupakan sumber penerimaan dalam negeri yang sangat dominan, artinya jika pajak tidak berjalan secara optimal maka akan mengganggu pembangunan di Indonesia. Dalam menjalankan tugas-tugas rutin negara dan melaksanakan pembangunan, negara membutuhkan biaya yang sangat besar. Biaya ini sebagian besar diperoleh dari penerimaan pajak.

Mengumpulkan pendapatan negara melalui pajak ternyata tidak semudah yang dibayangkan. Masih banyak wajib pajak pribadi dan wajib pajak badan yang tidak melaporkan jumlah harta dan penghasilan serta keuntungan yang harus diambil jumlah pajaknya. Khususnya wajib pajak badan yang banyak dikhawatirkan menyembunyikan jumlah penghasilan perusahaan yang sebenarnya dan diduga melakukan penggelapan pajak seperti transfer pricing dan sebagainya.

Terkait hambatan dalam mengumpulkan pajak sebagai pendapatan negara, direktorat pajak telah melakukan beberapa kebijakan yang diharapkan mampu meningkatkan kepatuhan wajib pajak, salah satunya adalah Tax Amnesty. Pengertian Tax Amnesty dalam undang-undang No. 11 Tahun 2016 adalah "program pengampunan yang diberikan oleh Pemerintah kepada Wajib Pajak meliputi penghapusan pajak yang seharusnya terutang, penghapusan sanksi administrasi perpajakan, serta penghapusan sanksi pidana di bidang perpajakan atas harta yang diperoleh pada tahun 2015 dan sebelumnya yang belum dilaporkan dalam SPT, dengan cara melunasi seluruh tunggakan pajak yang dimiliki dan membayar uang tebusan" (Pajak, Undang-undang No 11 Tahun 2016).

Pada dasarnya, Tax Amnesty telah memberikan persepsi kepada wajib pajak tentang pengampunan atas denda dan sanksi administrasi atas jumlah harta yang dilaporkan. Hal-hal terkait Tax Amnesty tertuang secara jelas didalam Undang-Undang No 11 Tahun 2016. Persepsi Tax Amnesty mampu memberikan respon positif terhadap penerimaan pajak di Kantor Pelayanan Pajak (Gunawan dan Sukartha, 2016), tetapi, pengetahuan secara jelas akan penerapan dan tata cara menyampaikan Surat Pemberitahuan sesuai dengan Undang-Undang No 11 Tahun 2016 untuk mendapatkan Tax Amnesty, belum secara merata dipahami oleh wajib pajak (Khairani, 2016).

Sejak disahkannya undang-undang No 11 Tahun 2016 tentang Tax Amnesty, banyak masyarakat yang memberikan respon positif terhadap kebijakan pemerintah terkait pengampunan pajak tersebut. Tidak sedikit masyarakat yang menarik Hartanya dari luar negeri untuk mengikuti Tax Amnesty. Bukan hanya wajib pajak pribadi tetapi juga wajib pajak badan.

Tax Amnesty diharapkan mampu meningkatkan pendapatan negara dari segi pajak agar dapat membantu pembangunan negara. Sebagian masyarakat meyakini bahwa Tax Amnesty hanya sebagai cara pemerintah untuk mengampuni para wajib pajak yang dengan sengaja menyimpan harta dan penghasilannya di luar negeri dengan tujuan menghindari tarif pajak di Indonesia. Namun, penelitian terdahulu menunjukkan bahwa dengan di berlakukannya Tax Amnesty akan memberi dampak positif pada pendapatan negara dan kepatuhan wajib pajak (Ngadiman \& Huslin, 2015), namun, informasi dan sosialisasi terkait Tax Amnesty dianggap belum memadai sehingga masih banyak masyarakat yang tidak mengetahui pelaksanaan dari Tax Amnesty 
(Khairani, 2016:34).

Penerapan Tax Amnesty kepada seluruh rakyat Indonesia, tentu akan di nikmati juga oleh masyarakat wajib pajak pribadi dan wajib pajak badan di Kota Batam. Kota Batam yang dikenal sebagai Kota Industri akan mampu menyumbang pendapatan pajak atas wajib pajak badan melebihi kota-kota lain di Indonesia. Kota Batam juga mengalami hambatan terhadap kepatuhan wajib pajak badan. Hal itu terbukti dari data yang menyatakan bahwa jumlah wajib pajak badan di Kota Batam adalah 53.618. Tetapi, hanya 18.932 wajib pajak badan yang melaporkan SPT (KPP Madya, 2014).

Adapun yang membedakan dari penelitian sebelumnya yaitu dalam hal tempat penelitian, dimana peneliti sebelumnya yang dilakukan oleh Gunawan dan Sukartha (2016) pada Direktorat Jenderal Pajak sedangkan penulis melakukan penelitian di Kantor Pelayanan Pajak Madya Kota Batam.

Penelitian ini bertujuan untuk mendapatkan bukti empiris mengenai pengaruh persepsi Tax Amnesty dan Pengetahuan wajib pajak badan terkait UU No.11 Tahun 2016 terhadap kepatuhan wajib pajak badan di kota Batam.

\section{Tinjauan Pustaka}

\section{Tax Compliance}

Teori tentang tax compliance pertama kali dikemukakan oleh Allingham dan Sandmo 1972. Teori ini mengasumsikan sedemikian tingginya tingkat ketidakpatuhan dari sisi ekonomi. Teori ini berkeyakinan tidak ada individu bersedia membayar pajak secara sukarela (voluntary compliance). Oleh sebab itu individu akan selalu menentang untuk membayar pajak (risk aversion). Untuk menjelaskan teorinya, Allingham dan Sadmo merumuskan suatu model :

$$
\begin{aligned}
& \mathbf{D}=\mathbf{D}(\mathbf{I}, \mathbf{t}, \mathbf{p}, \mathbf{f}) \\
& \text { Dimana : } \\
& \text { D } \quad \text { : } \text { declared income } \\
& \text { I } \quad \text { : pendapatan tetap } \\
& \text { t } \quad \text { : tarif pajak } \\
& \text { p : probabilitas untuk diaudit } \\
& \text { f : penalty rate }
\end{aligned}
$$

Menurut teori ini, faktor utama yang mempengaruhi kepatuhan pajak antara lain : pendapatan tetap (I), tarif pajak (t), probabilitas dilakukan audit (p), dan besarnya sanksi yang mungkin dikenakan (f). Individu diasumsikan memiliki endowment pendapatan yang tetap (I) yang harus dilaporkan ke pemerintah untuk menentukan besarnya pajak yang harus dibayarkannya. Declared Income (D) merupakan tingkat pendapatan wajib pajak yang dilaporkan pada tingkat tarif pajak (t). Pendapatan yang tidak dilaporkan tidak dikenai pajak, tetapi konsekuensinya individu dimungkinkan untuk diaudit dengan denda sanksi sebesar f yang harus di bayar untuk setiap pendapatan yang tidak dikenakan pajak. Individu akan memilih Declared Income (D) untuk memaksimalkan utilitas yang diharapkannya dari tindakan spekulasi penghindarannya (evasion gamble) (Hamonangan dan Mukhlis, 2012).

\section{Persepsi Tax Amnesty}

Baer dan LeBorgne, sebagaimana dikutip oleh Mikesell dan Ross, mendefinisikan tax amnesty sebagai penawaran terbatas-waktu oleh pemerintah untuk kelompok tertentu wajib pajak untuk membayar jumlah yang ditetapkan, dalam pertukaran untuk pengampunan kewajiban pajak (termasuk bunga dan denda), berkaitan dengan masa pajak sebelumnya, serta kebebasan tuntutan hukum.

Jacques Malherbe (2011) mengartikan tax amnesty sebagai kemungkinan membayar pajak dalam pertukaran untuk pengampunan dari jumlah kewajiban pajak (termasuk bunga dan denda), pengabaian penuntutan pidana pajak, dan keterbatasan untuk mengaudit penentuan pajak untuk jangka waktu tertentu.

Secara umum, program Tax Amnesty mampu mensyaratkan kepada wajib pajak mengenai pengampunan atas seluruh pajak yang terutang serta pajak yang tidak dilaporkan. Hal ini sejalan dengan penelitian Gunawan dan Sukartha (2016) yang mendefiniskan mengenai persepsi tax amnesty adalah pendapat wajib pajak terhadap informasi mengenai Tax amnesty secara langsung tanpa adanya pemahaman mendalam mengenai Tax amnesty. 
Persepsi Tax Amnesty mampu memberikan informasi secara umum dan gambaran mengenai program perpajakan yang sedang dilaksanakan oleh pihak pemerintah.
H1 $_{1}$ : Pengaruh persepsi Tax Amnesty terhadap kepatuhan wajib pajak badan

\section{Pemahaman Wajib Pajak}

Menurut Kamus Besar Bahasa Indonesia, pemahaman adalah proses, cara, perbuatan memahami atau memahamkan. Wajib pajak adalah orang pribadi atau badan (subjek pajak) yang menurut ketentuan peraturan perundang-undangan perpajakan ditentukan untuk melakukan kewajiban perpajakan, termasuk pemungut pajak atau pemotong pajak tertentu .

Menurut penelitian Hardiningsih (2011) yang berjudul faktor-faktor yang mempengaruhi kemauan membayar pajak, pengetahuan pajak adalah proses pengubahan sikap dan tata laku seorang wajib pajak atau kelompok wajib pajak dalam usaha mendewasakan manusia melalui upaya pengajarandan pelatihan. Pengetahuan peraturan perpajakan masyarakat melalui pendidikan formal maupun non formal dapat berdampak positif terhadap kesadaran wajib pajak untuk membayar pajak. Wajib pajak diberikan kepercayaan melalui sistem menghitung, memperhitungkan, membayar, melaporkan sendiri pajak yang terutang sehingga para wajib pajak akan fungsi dan system pembayaran pajak., Adanya system self assessment diharapkan dapat terwujud keadilan dan wajib pajak dapat mempelajari dan memahami peraturan dalam sistem perpajakan yang baru

Pada proses program tax amnesty, pemerintah telah mengeluarkan pedoman bagi wajib pajak yaitu UU No.11 tahun 2016. Di dalam UU No.11 tahun 2016 tertuang mengenai tebusan atas pajak terutang, sistem pelaporan untuk mengikuti tax amnesty serta denda yang akan diterima wajib pajak apabila terbukti tidak melaporkan jumlah harta secara jujur.

Setiap wajib pajak yang telah memahami peraturan dengan sangat baik, biasanya akan melakukan aturan perpajakan yang sesuai dengan apa yang tercantum di dalam peraturan yang ada. Indikator pemahaman akan peraturan perpajakan antara lain:

1. Pemahaman akan hak dan kewajiban perpajakan

2. Pemahaman akan sanksi perpajakan jika mereka lalai akan kewajibannya.

3. Pemahaman wajib pajak akan tarif tebusan atau denda yang harus diselesaikan.

$\mathbf{H}_{2}$ : Pengaruh pengetahuan Undang-Undang No.11 Tahun 2016 terhadap kepatuhan wajib pajak badan.

\section{Kepatuhan Wajib Pajak}

Menurut Harinurdin (2013), kepatuhan adalah suatu sikap atau prilaku untuk mengerjakan sesuatu sesuai dengan kaidah dan aturan yang berlaku. Kepatuhan dalam perpajakan merupakan suatu ketaatan untuk melakukan ketentuan-ketentuan atau aturan-aturan yang diwajibkan atau diharuskan dilaksanakan menurut perundang-undangan perpajakan. Kewajiban dan hak wajib pajak ini harus dijalankan secara seimbangan, apabila wajib pajak telah melaksanakan kewajibannya dalam perpajakan maka wajib pajak akan menerima haknya.

Menurut Resmi (2014) kewajiban pajak sebagai berikut :

a. Mendaftarkan diri untuk memperoleh Nomor Pokok Wajib Pajak (NPWP)

b. Menghitung dan membayar sendiri pajak dengan benar.

c. Mengambil sendiri surat pemberitahuan, mengisinya dengan benar dan memasukannya sendiri ke KPP dalam batas waktu yang telah ditentukan. Menyelenggarakan pembukuan atau pencatatan.

d. Jika diperiksa, Wajib:

1. Memperlihatkan dan atau meminjamkan buku atau catatan, dokumen yang menjadi dasarnyadan dokumen yang berhubungan dengan penghasilan yang diperoleh, kegiatan usaha, pekerjaan bebas wajib pajak. Atau objek yang terutang pajak 
2. Memberikan kesempatan untuk memasuki tempat atau ruangan guna memperlancar pemeriksaan

3. Memberikan keterangan yang diperlukan Menurut Resmi (2014) hak wajib pajak sebagai berikut:

1. Mengajukan surat keberatan dan banding.

2. Menerima tanda bukti pemasukan, pembetulan dan mengajukan permohonan penundaan pemasukan Surat Pemberitahuan (SPT).

3. Meminta pengembalian kelebihan pembayaran pajak.

4. Mengajukan permohonan penghapusan dan pengurangan sanksi serta pembetulan surat ketetapan yang salah.

5. Memberi kuasa kepada orang lain untuk melaksanakan kewajiban perpajakan.

$\mathbf{H}_{3}$ : Pengaruh persepsi Tax Amnesty dan pengetahuan Undang-Undang No.11 Tahun 2016 terhadap kepatuhan wajib pajak badan di Kota Batam

\section{Metode Penelitian}

\section{Populasi dan Sample}

Populasi dalam penelitian ini adalah wajib pajak badan yang terdaftar di Kantor Pelayanan Pajak di Kota Batam. Teknik pengambilan sample yang digunakan non probability sample (non acak) berupa purposive sampling dengan kriteria yaitu wajib pajak badan yang terdaftar di KPP Madya Kota Batam dan wajib pajak yang menyampaikan SPT hingga peride tax amnesty berakhir, yaitu tanggal 31 Maret 2017. Jumlah sample yang digunakan sebanyak 140 responden dengan menggunakan rumus slovin.

\section{Definisi dan Operasional Variable Variable Dependen}

Kepatuhan wajib pajak badan adalah wajib pajak yang diberi untuk menghitung, membayar dan melaporkan sendiri jumlah pajak yang seharusnya terhutang berdasarkan peraturan perundang undangan perpajakan. Indikator yang digunakan NPWP, bill, SPT dan Surat Tagihan Pajak.

\section{Variabel Independen}

Variable Independen dalam penelitian ini terdiri dari :

a. Persepsi Tax Amnesty

Secara umum, program Tax Amnesty mampu mensyaratkan kepada wajib pajak mengenai pengampunan atas seluruh pajak yang terutang serta pajak yang tidak dilaporkan. Hal ini sejalan dengan penelitian Gunawan dan Sukartha (2016) yang mendefiniskan mengenai persepsi tax amnesty adalah pendapat wajib pajak terhadap informasi mengenai Tax amnesty secara langsung tanpa adanya pemahaman mendalam mengenai Tax amnesty. Persepsi Tax Amnesty mampu memberikan informasi secara umum dan gambaran mengenai program perpajakan yang sedang dilaksanakan oleh pihak pemerintah.

b. Pengetahuan UU No.11 Tahun 2016

Suatu program dapat terlaksana dengan baik apabila disosialisasikan secara adil dan merata kepada seluruh wajib pajak. (Khairani, 2016). Indikator pada variable ini adalah Pemahaman Sanksi Pajak, Peraturan pemerintah, Sanksi Pidana, Sanksi administrasi, Pengenaan pajak.

\section{Teknik Pengolahan Data}

Uji Validitas dilakukan untuk mengetahui apakah alat yang digunakan bisa valid. Dari beberapa alat uji validitas yang ada peneliti memilih menggunakan korelasi product moment pearson untuk menguji validitas dari data yang diperoleh. Adapun kriteria pengambilan keputusan untuk mementukan validnya data ialah jika nilai $r$ hitung $\geq$ nilai $r$ tabel pada taraf signifikansi 0,05 (5\%).

Uji Reliabilitas merupakan suatu alat ukur dalam angket dikategorikan andal (reliable) jika alat ukur yang digunakan dapat mengukur secara konsiten. Sebuah faktor dinyatakan reliable/handal jika koefisien Alpha lebih besar dari 0.6.

Koefisien determinasi $\left(\mathrm{R}^{2}\right)$ digunakan untuk mengukur seberapa jauh kemampuan model dalam menerangkan variasi variable independen. Nilai $\mathrm{R}^{2}$ yang kecil berarti kemampuan variable-variable independen dalam menjelaskan variasi variable dependen amat terbatas. 
Uji T pada dasarnya menunjukkan pengaruh satu variabel independen secara individu (parsial). Langkah yang digunakan untuk menguji hipotesis ini adalah dengan menentukan level of significancenya.Level of significance yang digunakan sebesar $5 \%$ atau $(\alpha)=0,05$. Jika $\mathrm{t}>0,05$ maka Ha ditolak namun jika sign. $\mathrm{t}<0,05$ maka Ha diterima dan terdapat pengaruh yang signifikan antara variable independen dengan variable dependen (Ghozali, 2016).

Uji F dasarnya menunjukkan apakah semua variable independen yang mempunyai pengaruh secara bersama-sama terhadap variable dependen. Taraf signifikan $\alpha=0,05$, Jika $p$ value $<0,05$ maka Ha diterima, namun jika $\mathrm{p}$ value $>0,05$ maka Ha ditolak (Ghozali, 2016).

\section{Hasil dan Pembahasan}

Data dalam penelitian ini diperoleh dengan menyebarkan kuesioner secara langsung kepada wajib pajak badan yang menjadi subjek dari penelitian ini. Tabel 1 menyajikan distribusi kuesioner kepada responden. Kuesioner yang disebar dalam penelitian ini berjumlah 140 kuesioner, seluruh kuesioner yang disebar kembali dengan jumlah yang sama, sehingga total kuesioner yang digunakan adalah 140 kuesioner yang digunakan untuk tahap analisis.

\section{Tabel 1}

Rincian Jumlah Kuesioner

\begin{tabular}{lc}
\hline \multicolumn{1}{c}{ Keterangan } & Jumlah \\
\hline Kuesioner yang disebarkan & 140 \\
Kuesioner yang kembali dari responden & 140 \\
Kuesioner yang tidak diisi responden & 0 \\
Kuesioner yang dapat dijadikan sampel & 140 \\
Data outlier & 0 \\
\hline Total sampel yang digunakan & 140 \\
\hline \multicolumn{1}{c}{ Sumber: data hasil penelitian setelah diolah, 2017 }
\end{tabular}

Berdasarkan data yang diperolah dari 140 responden, pendidikan terakhir responden paling banyak SMK/SMA sebanyak 12 orang (8.57\%), Selanjutnya DIII berjumlah 38 orang $(27.14 \%)$, lalu jenjang pendidikan S1 sebanyak 70 orang $(50.00 \%)$ dan sisanya 20 orang (14.29\%) untuk S2. Sementara berdasarkan usia < dari 25 tahun dengan persentase $25.00 \%$ (35 orang), 62.14\% (87 orang) dengan usia 25-35 tahun, lalu $11.43 \%$ (16 orang) dengan usia $35-45,1.43 \%$ (2 orang) untuk usia 45-55 tahun dan tidak ada yang memiliki usia lebih dari > 55 tahun.
Tabel 2

Hasil Uji Validitas

\begin{tabular}{|c|c|c|c|c|}
\hline \multirow[b]{2}{*}{ Variabel } & \multicolumn{4}{|c|}{ Validitas } \\
\hline & Item & $\begin{array}{c}\mathbf{r} \\
\text { hitung }\end{array}$ & $\begin{array}{c}\mathbf{r} \\
\text { tabel }\end{array}$ & Kesimpulan \\
\hline \multirow{7}{*}{$\begin{array}{l}\text { Persepsi } \\
\text { Tax } \\
\text { Amnesty }\end{array}$} & Q1 & 0,752 & \multirow{7}{*}{0,166} & Valid \\
\hline & Q2 & 0,719 & & Valid \\
\hline & Q3 & 0,752 & & Valid \\
\hline & Q4 & 0,615 & & Valid \\
\hline & Q5 & 0,652 & & Valid \\
\hline & Q6 & 0,699 & & Valid \\
\hline & Q7 & 0,328 & & Valid \\
\hline \multirow{14}{*}{$\begin{array}{l}\text { Pemahaman } \\
\text { UU No } 11 \\
\text { Tahun } 2016\end{array}$} & Q8 & 0,752 & \multirow{14}{*}{0,166} & Valid \\
\hline & Q9 & 0,322 & & Valid \\
\hline & Q10 & 0,615 & & Valid \\
\hline & Q11 & 0,611 & & Valid \\
\hline & Q12 & 0,727 & & Valid \\
\hline & Q13 & 0,375 & & Valid \\
\hline & Q14 & 0,469 & & Valid \\
\hline & Q15 & 0,409 & & Valid \\
\hline & Q16 & 0,469 & & Valid \\
\hline & Q17 & 0,752 & & Valid \\
\hline & Q18 & 0,719 & & Valid \\
\hline & Q19 & 0,307 & & Valid \\
\hline & Q20 & 0,458 & & Valid \\
\hline & Q21 & 0,752 & & Valid \\
\hline \multirow{6}{*}{$\begin{array}{c}\text { Kepatuhan } \\
\text { Wajib Pajak } \\
\text { Badan }\end{array}$} & Q22 & 0,719 & \multirow{6}{*}{0,166} & Valid \\
\hline & Q23 & 0,752 & & Valid \\
\hline & Q24 & 0,615 & & Valid \\
\hline & Q25 & 0,531 & & Valid \\
\hline & Q26 & 0,586 & & Valid \\
\hline & Q27 & 0,719 & & Valid \\
\hline
\end{tabular}

Dalam penelitian ini peneliti terlebih dahulu melakukan uji validitas. Uji validitas terhadap kuesioner dilakukan kepada wajib pajak yang berada di KPP Madya Kota Batam sebanyak 30 responden. Hasil yang diperoleh menunjukkan bahwa $r_{\text {hitung }}>r_{\text {tabel, }}$, dengan nilai $r_{\text {tabel }}=0.166$, Sehingga semua pertanyaan dinyatakan valid.

Uji reliabilitas adalah tingkat kestabilan suatu alat pengukur dalam mengukur suatu kejadian, semakin tinggi reliabilitas suatu pengukur semakin stabil pula alat pengukur tersebut. Berdasarkan tabel 3 diperoleh Cronbach's alpha untuk variable persepsi tax amnesty $\left(\mathrm{X}_{1}\right)$ 0.764, pemahaman Undang-undang No.11 Tahun $2016\left(\mathrm{X}_{2}\right) 0.829$ dan kepatuhan wajib pajak badan $(\mathrm{Y})$ 0.774. Hasil tersebut menunjukkan bahwa semua variabel mempunyai Cronbach's Alpha diatas 0.60 sehingga dapat dikatakan semua pengukur masing-masing variabel dari kuisioner adalah reliabel sehingga untuk selanjutnya item pada masing-masing variable tersebut layak digunakan sebagai alat ukur

\section{Tabel 3}

Hasil Uji Reliabilitas

\begin{tabular}{lcccc}
\hline \multirow{2}{*}{ Variabel } & \multirow{2}{*}{$\begin{array}{c}\text { Jumlah } \\
\text { Item }\end{array}$} & Alpha & $\begin{array}{c}\text { Standar } \\
\text { Alpha }\end{array}$ & Kesimpulan \\
\cline { 3 - 4 } & & Cronbach & Cronbach & \\
\hline Persepsi Tax & 7 & 0,764 & 0,60 & Reliabel
\end{tabular}




\begin{tabular}{llccc} 
Amnesty & & & \\
\hline $\begin{array}{l}\text { Pemahaman } \\
\text { UU No.11 }\end{array}$ & & & & \\
Tahun 2016 & 14 & 0,829 & 0,60 & Reliabel \\
\hline $\begin{array}{l}\text { Kesimpulan } \\
\text { Wajib Pajak } \\
\text { Badan }\end{array}$ & 6 & 0,774 & 0,60 & Reliabel \\
\hline \multicolumn{5}{c}{ Sumber: Hasil Olahan SPSS }
\end{tabular}

Uji Normalitas digunakan untuk mengetahui apakah distribusi data mengikuti atau mendekati distribusi normal, data yang baik adalah data yang pola distribusinya normal.

Tabel 4

\begin{tabular}{|c|c|c|c|}
\hline & \multicolumn{3}{|c|}{ Hasil Uji Normalitas } \\
\hline & & X1 & $\mathrm{X} 2$ \\
\hline \multirow[t]{2}{*}{$\mathrm{N}$} & Valid & 140 & 140 \\
\hline & Missing & 0 & 0 \\
\hline \multicolumn{2}{|c|}{ Skewness } & 0,179 & 0,204 \\
\hline \multicolumn{2}{|c|}{ Std Error of Skewness } & 0,241 & 0,241 \\
\hline \multicolumn{2}{|c|}{ Kurtosis } & $(0,669)$ & $(0,205)$ \\
\hline \multicolumn{2}{|c|}{ Std Error of Kurtosis } & 0,478 & 0,478 \\
\hline
\end{tabular}

$\mathrm{X}_{1:}$

$$
\begin{aligned}
& \text { ZSkewness }=\frac{0.179}{\sqrt{\frac{6}{140}}}=0,743 \\
& \text { ZKurtosis }=\frac{-0.669}{\sqrt{\frac{24}{140}}}=-1.399
\end{aligned}
$$

$\mathrm{X} 2$ :

$$
\begin{aligned}
& \text { ZSkewness }=\frac{0.204}{\sqrt{\frac{6}{140}}}=0.846 \\
& \text { ZKurtosis }=\frac{-0.205}{\sqrt{\frac{24}{140}}}=-0.428
\end{aligned}
$$

Berdasarkan tabel 4 dapat diketahui bahwa hasil uji normalitas dengan Skewness dan Kurtosis untuk masing-masing variabel adalah sebesar $\mathrm{X}_{1}$ untuk Z hitung Skewness sebesar 0.179 dan Z hitung kurtosis sebesar -0.669. Pada $\mathrm{X}_{2} \mathrm{Z}$ hitung Skewness sebesar 0.204 dan Z hitung kurtosis sebesar - 0.205. Nilai tersebut lebih besar kecil dari pada Ztabel yaitu 1.96 maka diartikan bahwa data terdistribusi normal.

Uji autokorelasi bertujuan untuk menguji apakah dalam model regresi linear ada korelasi antara kesalahaan pengganggu pada periode $\mathrm{t}$ dengan kesalahan pengganggu pada periode $\mathrm{t}-1$ (sebelumnya). Uji autokorelasi dapat dilakukan dengan menggunakan nilai Drubin Watson dibandingkan dengan tabel Durbin Watson (dl dan du), dimana kriterianya jika $\mathrm{du}<\mathrm{d}_{\text {hitung }}<4$-du sehingga dapat dinyatakan bahwa tidak terjadinya autokorelasi.

Tabel 5

Hasil Uji Autokorelasi

\begin{tabular}{cc}
\hline Model & Durbin Watson \\
\hline $\mathbf{1}$ & $\mathbf{2 , 1 2 2}$ \\
\hline \multicolumn{2}{c}{ Sumber: Hasil olahan SPSS }
\end{tabular}

Berdasarkan tabel 5, dengan melihat nilai DW 1.914, nilai ini akan dibandingkan dengan nilai table signifikansi 5\%, jumlah sampel 140 (n) dan variable independen $2(\mathrm{k}=2)$, maka diperolah nilai $\mathrm{du}=1.760$. Nilai DW 2.122 lebih besar dari batas atas (du) yakni 1.760 dan kurang dari (4-du) 4-1.760 = 2.240. Persamaan yang terbentuk $1.760<2.122<2.240$, artinya dapat disimpulkan bahwa tidak terdapat autokorelasi.

Uji heterokedastisitas bertujuan untuk menguji apakah dalam sebuah model regresi terjadi ketidaksamaan varian dari residual atas satu pengamatan ke pengamatan lain. Jika varian dari residual atau satu pengamatan ke pengamatan lain tetap, maka disebut homokedastisitas dan jika berbeda disebut heteroskedastisitas. Untuk mendekati adanya heteroskedastisitas pada penelitian ini menggunakan uji Glejser. Pengujian Glejser ini membandingkan jika hasil signifikan > 0.05 maka disimpulkan model

\begin{tabular}{|c|c|c|}
\hline Variabel & $\begin{array}{l}\text { Nilai } \\
\text { Sig. }\end{array}$ & Kesimpulan \\
\hline $\begin{array}{l}\text { (X1) Persepsi Tax Amnesty } \\
\text { (X2) Pemahaman UU No.11 } \\
\text { Tahun } 2016\end{array}$ & $\begin{array}{l}0,834 \\
0,499\end{array}$ & $\begin{array}{c}\text { Tidak terjadi } \\
\text { heterokedastisitas } \\
\text { Tidak terjadi } \\
\text { heterokedastisitas }\end{array}$ \\
\hline
\end{tabular}
regresi tidak mengandung adanya heteroskedastisitas.

Tabel 6

Hasil Uji Heterokedastisitas

Sumber: Hasil olahan SPSS

Berdasarkan tabel 6 dengan melihat nilai signifikansi dapat dijelaskan sebagai berikut:

a. Persepsi tax amnesty (X1) memiliki nilai signifikansi 0,834, tidak terjadi heterokedastisitas, karena syarat terjadinya heterokedastisitas jika nilai signifikansi $<0,05$.

b. Pemahaman UU No.11 Tahun $2016\left(\mathrm{X}_{2}\right)$ memiliki nilai signifikasi 0,499 , tidak terjadi 
heterokedastisitas, karena syarat terjadinya heterokedastisitas jika nilai signifikansi $<0,05$.

Uji multikolonieritas bertujuan untuk menguji apakah model regresi ditemukan adanya korelasi antara variabel independen. Agar dapat menentukan apakah terdapat multikolinearitas dalam model regresi pada penelitian ini adalah dengan melihat nilai VIF (Variance Inflation Factor) dan tolerance serta menganalisis matrix korelasi variabel dependen.

Tabel 7

Hasil Uji Multikoliniearitas

\begin{tabular}{lccc}
\hline \multirow{2}{*}{ Model } & \multicolumn{2}{c}{ Colinearity Statistics } \\
\cline { 2 - 4 } & \multicolumn{2}{c}{ Tolerance } & VIF \\
\hline $\begin{array}{l}\text { X1_Persepsi Tax Amnesty } \\
\text { X2_Pemahaman UU No.11 } \\
\text { Tahun 2016 }\end{array}$ & 0,196 & 9,051 \\
\hline \multicolumn{3}{c}{ Sumber: Hasil olahan SPSS } \\
\hline
\end{tabular}

Berdasarkan tabel 7, Persepsi Tax Amnesty $\left(\mathrm{X}_{1}\right)$ memiliki nilai tolerance 0.196 lebih besar dari 0.10, Pemahaman UU No.11 Tahun $2016\left(\mathrm{X}_{2}\right) 0.196$ lebih besar dari 0.10. Dengan demikian dapat disimpulkan tidak terdapat korelasi variable-variabel bebas antara satu dengan yang lainnya, atau variable independen dalam penelitian ini bebas multikolonieritas karena VIF pada Persepsi Tax Amnesty $\left(\mathrm{X}_{1}\right)$ dan Pemahaman UU No.11 Tahun $2016\left(\mathrm{X}_{2}\right)$ memiliki nilai lebih kecil dari 10.00, yaitu 9,051.

Koefisien determinasi pada dasarnya digunakan untuk mengukur seberapa jauh kemampuan model dalam menerangkan suatu variasi variabel dependen (Ghozali, 2016). Berdasarkan dari table 8 besarnya besarnya nilai $\mathrm{R}$ (koefisien korelasi) sebesar 0.766 yang berarti bahwa variabel dependent dan independent dapat dikategorikan memiliki hubungan linear yang cukup. Nilai Adjusted R Square adalah 0.581 hal ini mengidentifikasikan bahwa Persepsi Tax Amnesty dan Pemahaman UU No11 Tahun 2016 berpengaruh sebesar 58,7\% terhadap kepatuhan wajib pajak badan sedangkan sisanya sebesar $58,1 \%$ dipengaruhi oleh variabel atau faktor lain diluar penelitian.

$$
\text { Tabel } 8
$$

Hasil Koefisien Determinasi

\begin{tabular}{cccc}
\multicolumn{4}{c}{ Hasil Koefisien Determinasi } \\
\hline Model & R $\quad$ R Square & $\begin{array}{c}\text { Adjusted R } \\
\text { Square }\end{array}$ & $\begin{array}{l}\text { Std. Error of } \\
\text { the Estimate }\end{array}$
\end{tabular}

Uji statistik t dilakukan untuk menunjukkan seberapa jauh satu variabel independen secara individual dalam menerangkan variabel dependen, dengan kriteria Sig <0,05 maka Ho diterima, sedangkan jika Sig > 0,05 maka Ho ditolak.

Berdasarkan dari tabel 9 dapat dianalisis persamaan regresi sebagai berikut :

$\mathrm{KPWB}=3.666+0.578 \mathrm{X}_{1}$

KPW = Kepatuhan Wajib Pajak Badan;

PTA $=$ Pesepsi Tax Amnesty

Nilai koefisien regresi variabel Persepsi Tax Amnesty $\left(\mathrm{X}_{1}\right)$ yaitu 0,578 atau $57,8 \%$, artinya jika persepsi tax amnesty mengalami kenaikan satuan, maka kepatuhan wajib pajak badan akan mengalami kenaikan sebesar 0,578 atau 57,8\%, diketahui bahwa nilai signifikansi hitung lebih kecil dari nilai signifikansi standar $(0,01<0,05)$.

Pengujian hipotesis dilakukan dengan membandingkan nilai signifikansi 0,05. Untuk variabel pengetahuan peraturan perpajakan $\left(\mathrm{X}_{1}\right)$ nilai signifikasinya 0.01. Dengan demikian dapat dikatakan bahwa nilai signifikan $0.01<0.05$. Nilai koefisiennya $57.8 \%$ dari variabel $\mathrm{X}_{1}$ bernilai positif yaitu 0.578 . Hal ini menunjukkan bahwa penelitian ini dapat membuktikan Persepsi Tax Amnesty $\left(\mathrm{X}_{1}\right)$ berpengaruh dan signifikan terhadap kepatuhan wajib pajak badan. Dengan demikian $\mathbf{H}_{1}$ terdukung.

Tabel 9

\section{Hasil Uji Statistik t}

Persepsi Tax Amnesty terhadap Kepatuhan Wajib Pajak

Badan

\begin{tabular}{|c|c|c|c|c|}
\hline \multirow{2}{*}{\multicolumn{2}{|c|}{ Model }} & \multirow{2}{*}{$\begin{array}{c}\begin{array}{c}\text { Unstandardized } \\
\text { Coefficients }\end{array} \\
\text { B } \\
\end{array}$} & \multirow[t]{2}{*}{$\mathbf{T}$} & \multirow[t]{2}{*}{ Sig. } \\
\hline & & & & \\
\hline 1 & (Constant) & 3,666 & 3,055 & ,025 \\
\hline & $\mathrm{X} 1$ & ,578 & 3,489 &, 001 \\
\hline
\end{tabular}

Berdasarkan dari tabel 10, Nilai koefisien regresivariabel Pemahaman Undang-Undang No.11 Tahun $2016\left(\mathrm{X}_{2}\right)$ yaitu 0,085 atau $8,5 \%$, artinya jika Pemahaman Undang-Undang No.11 Tahun 2016 mengalami kenaikan satuan, maka kepatuhan wajib pajak badan akan mengalami kenaikan sebesar 0,085 
atau $8,5 \%$, diketahui bahwa nilai signifikansi hitung lebih kecil dari nilai signifikansi standar $(0,03<0,05)$.

\section{Dengan demikian $\mathbf{H}_{2}$ terdukung}

Persamaan regresi:

KWPB: $3.666+0.085 \mathrm{X}_{2}$

Tabel 10

Hasil Uji Statistik t

Pemahaman UU No. 11 Tahun 2016 terhadap Kepatuhan

\begin{tabular}{|c|c|c|c|c|}
\hline \multicolumn{5}{|c|}{ Wajib Pajak Badan } \\
\hline & & $\begin{array}{c}\text { Unstandardized } \\
\text { Coefficients }\end{array}$ & $\mathbf{T}$ & Sig. \\
\hline \multicolumn{2}{|c|}{ Model } & $\mathbf{B}$ & & \\
\hline$\overline{1}$ & (Constant) & 3,666 & 3,055 & ,025 \\
\hline & $\mathrm{X} 2$ & 085 & 2,534 & 003 \\
\hline
\end{tabular}

Sumber: Hasil olahan SPSS

Untuk mengetahui apakah variabel independen secara simultan berpengaruh signifikan terhadap variabel dependen, maka dilakukan uji F. derajat kepercayaan yang digunakan adalah 0.05. Apabila nilai $\mathrm{F}$ hasil lebih besar dari pada $\mathrm{F}$ table maka hipotesis yang menyatakan semua variabel independen secara simultan berpengaruh signifikan terhadap variabel dependen.

Berdasarkan tabel 10 dapat dianalisis persamaan regresi sebagai berikut :

\section{$\mathrm{KPWB}=\alpha+\beta_{1} \mathrm{PTA}+\beta_{2}$ PUU $\varepsilon$ \\ KPWB $=3,666+3,489+2,534+\varepsilon$}

$\mathrm{KPWB}=$ Kepatuhan wajib pajak badan; $\mathrm{PTA}=$ Persepsi Tax Amnesty ; PUU = Pemahaman Undang-Undang No.11 Tahun 2016 ; e= Standar eror

Nilai $F$ hitung sebesar 97.236 dengan signifikansi 0.000 karena nilai signifikasi yaitu 0.00 $<0.05$, hal ini menunjukkan bahwa variabel independen (Persepsi Tax Amnesty dan Pemahaman UU No.11 Tahun 2016) secara bersama-sama mampu menjelaskan pengaruhnya terhadap variabel dependen (Kepatuhan Wajib Pajak Badan). Dengan demikian $\mathbf{H}_{3}$ terdukung.

Tabel 11

Hasil Uji Statistik F (Simultan)

\begin{tabular}{ccc}
\hline Model & F & Sig \\
\hline 1 & 97,236 & 0,000 \\
\hline
\end{tabular}

Sumber: Hasil olahan SPSS
Berdasarkan uji statistik yang telah dijelaskan, dapat disimpulkan bahwa Persepsi Tax Amnesty memiliki pengaruh terhadap Kepatuhan Wajib Pajak Badan atau hipotesis diterima. Hal ini disebabkan nilai signifikansi hitung < signifikansi standar $(0,01<$ $0,05)$, sedangkan syarat untuk hipotesis diterima jikan nilai signifikansi hitung lebih kecil atau sama dengan nilai signifikansi standar.

Penelitian ini sejalan dengan penelitian terdahulu yang dilakukan oleh Gunawan dan Sukartha (2016), yang mengatakan bahwa Persepsi Tax Amnesty berpengaruh terhadap Kepatuhan Wajib Pajak. Menurut Gunawan dan Sukartha (2016), bahwa informasi terkait program pengampunan pajak dan sistem tebusan Tax Amnesty mampu menarik Wajib Pajak untuk menyatakan jumlah harta sebenarnya dan membayar denda atas harta yang selama ini tidak dilaporkan, sehingga persepsi mampu medorong seseorang untuk mengambil keputusan dan melakukan sesuatu berdasarkan informasi yang diterima.

Penelitian ini juga bertujuan untuk melihat seberapa besar pengaruh Pemahaman UU No.11 Tahun 2016 terhadap kepatuhan wajib pajak badan. Dari hasil pengujian hipotesis ditemukan bahwa sanksi pajak tidak berpengaruh dan tidak signifikan terhadap kepatuhan wajib pajak. Dari hasil penelitian yang dilakukan penulis sanksi pajak tidak berpengaruh terhadap kepatuhan wajib pajak. Berdasarkan uji statistik yang telah dijelaskan, dapat disimpulkan bahwa Pemahaman Undang-Undang No.11 Tahun 2016 memiliki pengaruh terhadap Kepatuhan Wajib Pajak Badan atau hipotesis diterima. Hal ini disebabkan nilai signifikansi hitung < signifikansi standar $(0,01<0,05)$, sedangkan syarat untuk hipotesis diterima jikan nilai signifikansi hitung lebih kecil atau sama dengan nilai signifikansi standar. Pada KPP Madya Kota Batam, salah satu aspek penting dalam meningkatkan Kepatuhan Wajib Pajak Badan adalah sosialisasi mengenai peraturan dan informasi mengenai pajak. Hal ini agar mampu memberikan pemahaman yang baik terhadap Wajib Pajak Badan dan meningkatkan Kepatuhan Wajib 
Pajak Badan.

Penelitian ini sejalan dengan penelitian terdahulu yang dilakukan oleh (Deviana, 2012), (Khairani, 2016) dan (Dharma dan Suadarna, 2014). Menurut Deviana (2012), Pemahaman peraturan berpengaruh terhadap kepatuhan wajib pajak. Hal ini juga dikemukakan oleh Kharani (2016), yang mengatakan bahwa Pemahaman Undang-Undang No.11 Tahun 2016 berpengaruh signifikan terhadap Kepatuhan Wajib Pajak. Disisi lain, Dharma dan Suadarna (2014), mengatakan bahwa untuk mencapai pemahaman akan suatu peraturan atau undang-undang perpajakan, maka dibutuhkan sosialisasi perpajakan.

Wajib Pajak Badan Kota Batam yang pada hal ini ditemui peneliti di KPP Madya Kota Batam mengatakan bahwa ketertarikan untuk mengikuti Tax Amnesty, setelah Wajib Pajak Badan mengetahui berapa Tarif Tebusan yang tertuang didalam Undang-Undang No.11 Tahun 2016. Hal ini membuktikan bahwa Pemahaman Wajib Pajak terhadap Undang-Undang No.11 Tahun 2016 berpengaruh terhadap Kepatuhan Wajib Pajak Badan di Kota Batam.

Penelitian ini bertujuan untuk mengetahui ada atau tidaknya pengaruh hubungan antara variable terikat yaitu kepatuhan wajib pajak badan terhadap semua variable bebas yaitu persepsi tax amnesty dan pemahaman UU No.11 Tahun 2016. Hasil penelitian menunjukkan bahwa variabel independen(persepsi tax amnesty dan pemahaman UU No.11 Tahun 2016) berpengaruh signifikan terhadap kepatuhan wajib pajak badan. Dari hasil yang diperoleh dapat disimpulkan antar variable independen berpengaruh terhadap kepatuhan wajib pajak badan badan dalam membayar pajak, melaporkan ataupun kesadaran wajib pajak untuk membayarkan pajak tepat waktu.

Pada lain sisi terdapat faktor lain yang diduga menjadi pemicu meningkatnya kepatuhan wajib pajak badan saat Tax Amnesty dideklarasikan. Salah satunya adalah wacana yang diucapkan oleh Menteri Keuangan Republik Indonesia yaitu Ibu Sri Mulyani. Pada wacana tersebut dijelaskan, jika wajib pajak badan diketahui tidak mengikuti Tax Amnesty hingga periode berakhir maka akan ada risiko yang diterima, adapun jenis risiko yang diterima adalah:

a. Jumlah harta yang tidak dideklarasikan akan dikenakan denda sebesar $25 \%$ dari total harta tersebut.

b. Denda sebesar $2 \%$ dari total harta yang harus dibayar perbulan.

Penulis belum menemukan penelitian sejenis yang melakukan uji simultan dengan kedua variabel independen seperti persepsi tax amnesty dan pemahaman UU No.11 Tahun 2016 terhadap variable dependen yaitu kepatuhan wajib pajak badan.

\section{Kesimpulan}

Penelitian ini bertujuan untuk mengetahui pengaruh variabel persepsi tax amnesty dan pemahaman UU No.11 Tahun 2016 terhadap kepatuhan wajib pajak badan di Kota Batam. Berdasarkan hasil perhitungan dan analisis yang telah dilakukan maka dapat dibuat kesimpulan bahwa:

a. Persepsi Tax Amnesty berpengaruh terhadap Kepatuhan Wajib Pajak Badan. Persepsi merupakan suatu proses kognitif yang dialami oleh setiap orang dalam memahami informasi. Persepsi mampu mendorong seseorang untuk mengambil keputusan dan melakukan sesuatu berdasarkan informasi yang diterima

b. Pemahaman Undang-Undang No.11 Tahun 2016 berpengaruh terhadap Kepatuhan Wajib Pajak Badan. Pemahaman maksudnya adalah mengerti secara baik mengenai peraturan tata cara serta jumlah tebusan yang tertuang didalam Undang-Undang No.11 Tahun 2016 mengenai Tax Amnesty.

c. Persepsi Tax Amnesty dan Pemahaman Undang-Undang No.11 Tahun 2016 berpengaruh terhadap kepatuhan wajib pajak badan. Kepatuhan dapat ditingkatkan apabila informasi progam pajak yang diterima oleh wajib pajak badan disertai dengan pemahaman atas program pajak yang sedang dilaksanakan. 
Keterbatasan pada penelitian ini:

a. Penelitian hanya berdasarkan hal-hal yang terkait dengan Tax Amnesty.

b. Ada beberapa Wajib Pajak Badan yang mungkin mengisi kuesioner dalam keadaan tergesa-gesa.

c. Peneliti meneliti di KPP Madya Kota Batam pada bulan Februari yang berarti satu bulan sebelum program Tax Amnesty berakhir.

Saran untuk penelitian berikutnya :

a. Agar penelitian selanjutnya memilih sampel tidak hanya pada wajib pajak badan saja, akan tetapi pada wajib pajak perorangan, serta menambah jumlah koresponden.

b. Selain itu, perhatikan juga apakah saat akan diberikan pertanyaan, kondisi koresponden dalam keadaan sibuk atau tidak. Mengingat bahwa saat peneliti melakukan penelitian, sebagian besar kondisi wajib pajak badan dalam keadaan sibuk dan serta kantor KPP Madya Kota Batam dalam keadaan ramai pengunjung, sehingga mungkin saja dapat menurunkan daya konsentrasi koresponden dalam menjawab pertanyaan.

\section{Daftar Pustaka}

Allingham, Michael G and Agnar Sandmo, 1972. Income Tax Evasion: A Theoritical Analysis, Journal of Publics Economics, 1: pp.323-328.

Ansari, A. (2015). Teknik pengolahan data dan penyajian data. Jakarta: Sahabat Pena

Bagiada, I. M., \& Darmayasa, I. N. (2016). Tax Amnesty Upaya Membangun Kepatuhan Sukarela. Simposium Nasional Akuntansi Vokasi V. 1-24.

Deviana, D. (2012). Kepatuhan Wajib Pajak Badan dalam Perspektif Tax Profesional, Prosiding Seminar Nasional Multi Disiplin Ilmu \& Call for Papers Unisbank (sendi_u) 1-10.

Dharma \& Suardana (2014). Pengaruh Kesadaran Wajib Pajak, Sosialisasi Perpajakan, Kualitas Pelayanan Pada Kepatuhan Wajib Pajak, E-Jurnal Akuntansi Universitas Udayana; 2014 : 340-353
Ekonomi, W. (2015, Maret 27). KPP : Kepatuhan Wajib Pajak Rendah. Batam, Kepulauan Riau, Indonesia.

Ghozali, I. (2016). Aplikasi Analisis Multivariate dengan Program IBM SPSS 23 Edisi Kedelapan. Semarang: Badan Penerbit Universitas Diponegoro.

Gunawan Andri, Sukartha (2016), Pengaruh Persepsi Tax Amnesty, Pertumbuhan Ekonomi dan Transformasi Kelembagaan Direktorat Jenderal Pajak Pada penerimaan pajak pdf, E-Jurnal Akuntansi Universitas Udayana Vol.17.3. Desember 2036-2060

Hardiningsih, P. (2011). Faktor-faktor yang Mempengaruhi Kemauan Membayar Pajak. 13.

Harinurdin, E. (2013). Perilaku Kepatuhan Wajib Pajak Badan. 1-8.Metodologi Penelitian Bisnis (Salah Kaprah dan Pengalaman-Pengalaman edisi 6). Yogyakarta BPFE-Yogyakarta

Hartono, Jogiyanto,M. B. (2016). Indonesia. (2016). Undang-Undang No 11 Tahun 2016 Tentang Pengampunan Pajak. Jakarta.

Jacques Malherbe, (2011), Tax Amnesties, Kluwer Law International BV, The Nederlands . (2007). Penjelasan UU No 28 tahun 2007. Jakarta: Pemerintah Republik Indonesia. (1945). Undang-Undang Dasar 1945. (2016). Implementasi Tax Amnesty. Jakarta.

Khairani, Siti. (2016). Pemahaman Undang-Undang No 11 Tahun 2016. 34-61

(2012). Dimensi Ekonomi Perpajakan dalam Pembangunan Ekonomi. Jakarta: Raih Asa Sukses.

Malherbe, J. (2008). Tax Amnesty in 2006. Landscape.

Mulyani, Sri. (2016, November 27). Menkeu Sebutkan Risiko Wajib Pajakjika Tak Ikut Tax Amnesty Web site:

http://batamnews.allco.id/berita-18034-menkeu -sebutkan-risiko-wajib-pajak.html

Nar, M. (2015). The Effects of Behavioral Economics on Tax Amnesty. International Journal of 
Economics and Financial Vol 5,Issue 2, 580-589.

Ngadiman, \& Huslin, D. (2015). Pengaruh Sunset Policy, Tax Amnesty dan Sanksi Pajak terhadap Kepatuhan Wajib Pajak. Jurnal Akuntansi, 225-241.

Republik Indonesia (2007). Undang Undang nomor 28 tentang Ketentuan Umum Perpajakan.

(2016). Undang-undang No 11

Tahun 2016. Jakarta: Direktorat Jenderal Pajak.

Resmi, S. (2014). Perpajakan Teori dan Kasus. Jakarta: Salemba Empat.

Schaltegger, B. T. (2003). Tax Morale and fiscal policy. Centre of Research in Economics, Management and Art (CREMA). 30.

Suadarna, G. P. (2014). Pengaruh Kesadaran Wajib Pajak ,Sosialisasi Perpajakan, Kualitas Pelayanan pada Kepatuhan Wajib Pajak. E-Jurnal Akuntansi Universitas Udayana 6.1 (2014) 340-353.

Sugiono. (2016). Metode pengolahan data administrasi. Jakarta: Sahabat Pena

Sukartha, A. G. (2016). Pengaruh Persepsi Tax Amnesty, Pertumbuhan Ekonomi dan Transformasi Kelembagaan Direktorat Jenderal Pajak pada Penerimaan Pajak. E jurnal Universitas Udayana, Vol 17 No 3, $1-25$.

Suhendra, E. (2010). Pengaruh Tingkat Kepatuhan Wajib Pajak Badan Terhadap peningkatan Penerimaan Pajak Penghasilan Badan. Journal Universitas Gunadarma, Vol 15 No 1.

Tim Penyusun Pusat Kamus. (2007). Kamus Besar Bahasa Indonesia edisi ketiga. Jakarta:Balai Pustaka

Waluyo. (2011). Perpajakan Indonesia. Jakarta: Salemba Empat

Web Site: www.pajak.go.id (2016, June 11). Apa Itu Amnesty ? Retrieved from Dirjen Pajak diunduh:14 Maret 2018 